European journal of American studies

\title{
"A Peculiar National Character": Transatlantic Realignment and the Birth of American Cultural Nationalism after 1815
}

Jaap Verheul

\section{OpenEdition}

\section{Journals}

Édition électronique

URL : https://journals.openedition.org/ejas/9638

DOI : 10.4000/ejas.9638

ISSN : 1991-9336

Éditeur

European Association for American Studies

Référence électronique

Jaap Verheul, «"A Peculiar National Character": Transatlantic Realignment and the Birth of American Cultural Nationalism after $1815 »$ European journal of American studies [En ligne], 7-2 | 2012, mis en ligne le 03 avril 2012, consulté le 08 juillet 2021. URL : http://journals.openedition.org/ejas/9638 ; DOI : https://doi.org/10.4000/ejas.9638

Ce document a été généré automatiquement le 8 juillet 2021

Creative Commons License 


\title{
"A Peculiar National Character": Transatlantic Realignment and the Birth of American Cultural Nationalism after 1815
}

\author{
Jaap Verheul
}

Just as 1776 saw the birth of political independence for the United States as a new nation, the year 1815 saw the quickening of its quest for cultural independence. The year that finally brought an end to the War of 1812 was the starting point for a wave of national pride in which Americans redefined their own national purpose, their collective cultural identity, and - perhaps most of all - their relation to the old World. This recalibration of the transatlantic ties and the fundamental changes it brought to the American perception of Europe are perhaps the most intriguing and problematic features of the emerging American nationalism that characterized the early nineteenth century. It fed a vitriolic anti-European rhetoric that soon informed American foreign relations and economic policy, and would never completely disappear from the American intellectual horizon. But it also changed the way Americans defined what it meant to be a great nation.

1 The cultural dialogue with the old World was crucial to the emergence of a new era of cultural nationalism in the United States. As Henry Adams famously put it: "In 1815 for the first time Americans ceased to doubt the path they were to follow. Not only was the unity of their nation established, but its probable divergence from older societies was also well defined." That departure from "older societies" was particularly critical, for Adams believed that the United States had finally escaped from the "Old-World development" and could define its national ethos, character and identity in contrast to Europe. By not only adopting its own political system, but also following an independent course in social, religious, literary and scientific development, he felt, "the difference between Europe and America was decided." Since it was henceforward inconceivable that the United States would revert to European models and ways of thinking, Adams concluded that "a new episode in American history began in 1815." 1 
2 Although Adams and others have argued that a new American cultural nationalism developed in self-confident opposition to the old World, the powerful cultural thralldom to Europe was not broken that easily or suddenly. In fact, the American quest for nationality shows the familiar complexities of a cultural decolonization process. ${ }^{2}$ Although American intellectuals redefined Europe as a useful "other" against which they could construct their own collective identity, they long retained a legacy of European standards of civilization and esthetics. More importantly, they were thoroughly influenced by European ideas about the relationship between culture and nation. Ironically, the cultural differentiation with the old World was informed by new standards of nationhood that were developed in England, and in particular in continental Europe, the romantic laboratory of nationalism of the early nineteenth century. ${ }^{3}$

\section{The Tenacity of Trans-Atlantic Ties}

Until the young republic entered its second war with the former mother country, few of its citizens expressed concerns about the cultural identity of their nation. When Americans pondered the rising glory of their nation, it had mostly been as an "Empire of Liberty," as Jefferson famously named it, which had explored a new system of government based on freedom and equality. As Joyce Appleby argues, the first generation of Americans who inherited the Revolution felt that the War of Independence simply had not supplied "the shared sentiments, symbols, and social explanations necessary for an integrative national identity." Although the revolution had provided the nation with shared histories, documents and sentiments, and foreign travelers already noticed distinctive American characteristics, the ideal of a national culture took a longer time to emerge. The revolutionary generation had defined nationhood characteristically in terms of political, social and economic participation, and had little interest - or accomplishments, for that matter - in culture and refinement. ${ }^{5}$ It took another war to start that process of cultural nationalism.

3 While they treasured their political independence and nationalism, prior to 1815 most Americans embraced the cultural ties with the old World. As Gordon S. Wood emphasizes, the revolutionary generation still thought in terms of a translatio imperii and "never intended to create an original and peculiar indigenous culture. [...] They were seeking not to cut themselves off from Europe's cultural heritage but to embrace it and in fact to fulfill it." ${ }^{6}$ The revolutionary generation had been emphatically cosmopolitan, and if anything, aimed to import as many fruits of Enlightenment culture from Europe into their young nation as possible. Jefferson and other founders lived parts of their lives in Europe, mentally if not physically. These Americans were not seeking to separate themselves from western civilization, but saw themselves as members of a cosmopolitan community, a "trans-Atlantic intellectual fraternity." In the concept of culture that had developed during the Enlightenment, all civilized people belonged to the same family of nations, and all nations were marching towards the same goal of human perfection and artistic achievement.

David Hackett Fischer and others have reminded us that Americans clung to the English language and folkways with feelings of nostalgia, even if they vehemently rejected English political tyranny, autocracy and monarchy. ${ }^{8}$ London remained the undisputed cultural center of the new republic. For standards of taste in painting, sculpture, 
architecture, literature, poetry and even language, Americans still referred to England. ${ }^{9}$ As far as there was an element of cultural transatlantic competition, it was because Americans were eager to prove that they, too, could contribute to the common achievements of humanity. Also linguistically, the former colonies shared an undisputed common cultural core with England, even if its inhabitants sometimes diverged from the prescribed practice of pronunciation and spelling. Early proposals to discard the English language were therefore laughed away. As one delegate at the Constitutional Convention joked: "it would be more convenient for us to keep the language as it was, and make the English speak Greek." ${ }^{10}$

5 Yet within this seemingly unbroken transatlantic civilization early calls for American cultural independence could be heard, even if they did not coalesce into a shared program of cultural nationalism. Significantly, anti-English feelings did make their way into some early proposals to liberate American English from the linguistic norms of the former mother country, challenging of the most obvious forms of shared cultural heritage. The lawyer and lexicographer Noah Webster would become the most outspoken proponent of a separate American dictionary and orthography. As he already insisted in 1789: "As an independent nation, our honor requires us to have a system of our own in language as well as government." His attempt to "declare American linguistic independence" was largely practical and had been informed by ideas about development and standardization of languages that were current in Europe.

6 Recognizing that language was an essential ingredient of cultural identity, Webster was convinced that a uniform national language was a requirement for "political harmony" and national unity, and would help to "inspire us with a suitable respect for our own national character." " $\mathrm{He}$ firmly rejected Anglophilia and repeatedly warned that the linguistic ties with "a transatlantic nation" were the result of perilous foreign cultural influences on American taste and manners. In a flood of political essays he continued to caution that the American Revolution could not be completed if his country would remain culturally dependent on England. To Webster's dismay, however, his warnings fell on deaf ears or met with ridicule, as most of his collocutors preferred a more gradual development of the American language. He was forced to tone down his reform proposals and it was only well after 1815 that his dictionary was widely adopted and Webster became the "Schoolmaster to America."12

7 Similarly, indigenous writers who tried to develop an authentic style had difficulty in receiving recognition from American readers and critics during the first decades of independence. The authors known as the Connecticut Wits, who celebrated their own society but modeled their work on English literary styles, met with some success. But the literary career of a more original writer such as Charles Brockden Brown, who developed his own style independent from English literary norms, was bitterly shortlived. Lack of sales and popularity as American novelist drove him to spend his last years as political pamphletist and editor of his own magazines. ${ }^{13}$

Charles Brockden Brown was only recognized and heralded as an early American literary nationalist in 1815 , five years after his death. His first biography, which was published in that year, started off with a sharp condemnation of the difficulties Brown had faced in competing with English authors. His close friend and biographer, the dramatist and painter William Dunlap, now hailed Brown as one of the first adventurers of American fiction "who first saw the propriety of men in a new and 
better political state, throwing off the shackles of an absurd prejudice in favour of European opinions and writings, as they had thrown from them the proffered chains and rejected the pretensions of European tyranny." As if to enlist his protagonist in a new struggle for cultural independence, Dunlap reminded his readers that Brown had identified the "remoteness of their situation from the ordinary range of European politics and influence of European ambition." ${ }^{14}$ Following Dunlop in his praise, other writers such as Henry Wadsworth Longfellow and William Hickling Prescott in the subsequent decades also posthumously rediscovered Brockden Brown as the father of a truly indigenous American literature. ${ }^{15}$

Until the War of 1812, the American society treasured its political independence and economic prowess, but remained well-embedded in the cultural traditions of the old Word. Put differently, although the War of Independence and the debate over the Constitution had created a strong sense of statehood, the new republic was not yet united by a cultural nationalism, which presupposed a unique, shared culture. It would take another war to push the United States into an era of nationalism that fostered ideas of exceptionalism and cultural isolation.

\section{The Second War for Independence}

Accentuating the end of warfare as a new beginning for the nation, the War of 1812 was already dubbed a "Second War for Independence" by the first history of the war that was published in $1815 .{ }^{16}$ This second battle for freedom was not only fought with guns, however, but also became a battle of words. The war marked the beginning of a true communication revolution in which a host of new periodicals, newspapers and new publishing houses connected the American citizens and formed a national forum of opinion that was vital for the construction of a national identity. ${ }^{17}$ These new means of communication were used to calibrate and interrogate the relation to the old World.

Even when the War of 1812 was still being fought on the high seas and the American continent, Americans prepared for what one scholar called "a campaign of periodicals" against the former mother country by starting literary and cultural journals to express their new national sentiment. Some magazines explicitly referred to the parallel between the two battle fields. The Democratic leaning Port-Folio, for instance, encouraged its writers to "emulate the ambition, diligence and zeal that have so eminently characterized our gentlemen of the sword," and hoped the United States would in a few years "become as renowned in literature, as she is in arms." 18

11 Between 1815 and 1830 no less than thirty one new periodicals were founded. Many of these journals encouraged native writers to rise against foreign interference and shed intellectual homage to England. Among them was the Portico started in 1816 in Baltimore, the self-professed "Rome of the United States," by wealthy literati who aimed to meet European standards of culture, not only by erecting monuments, constructing buildings and founding museums, but also by raising a new generation of "native genius [...] to produce a literature that would be a worthy asset to America's reputation." 19 The new journal decried "the literary sycophants who would Europeanize America," explicitly defied British magazines and their reviewers, and claimed their own national literature, and - almost as important - language. "Americans," the editor of the Portico boasted, "are perfectly competent to carry on the 
'war of words' with any Europeans." Instead of leaning on foreign education, they were to "exercise [their] own talents."

It was the North American Review, however, that would rapidly become the most influential magazine of the republic, unmodestly claiming to print "the best that has been said and thought." ${ }^{21}$ The magazine was founded in May 1815 by William Tudor, a wealthy merchant who is credited with the first reference to Boston as "the Athens of America." Just returning from Europe, he intended his new periodical as a rival to leading British magazines he had read there, such as the Edinburgh Review and the London-based Quarterly Review. Transatlantic cultural rivalry was essential to Tudor's publication project. His magazine aimed to foster genuine American culture by countering the criticism of American society and culture that was voiced by British periodicals. "The spirit of the work was national and independent as regarded foreign countries," Tudor explained..$^{22}$ In its pages collective opinion was formed about politics, history, science and literature in the American republic, but it also closely watched new ideas, developments and-most of all-recent literature that originated from Europe. In spite of its nationalistic agenda, it remained emphatically transatlantic and comparative in its approach and tastes, and for instance eagerly debated English romanticism and German philosophy. As Tudor intended, the North American quickly became the most important forum for the new cultural nationalism that spread within the young nation. ${ }^{23}$

\section{The Quest for National Character}

In its first years, the North American Review most of all expressed the ambitions of the cultural elite that dominated Boston intellectual life, as Tudor managed to recruit many of these Brahmins to write for his journal. A fitting opening volley in the new battle of words was delivered in 1815 by the Boston physician Walter Channing. Dr. Walter, who would become the nation's foremost obstetrician, was the younger brother of William Ellery Channing, the author and clergyman who would become the founder of the Unitarian church and one of the most influential intellectual leaders of Boston. ${ }^{24}$ In a long article that was printed in two issues of the first volume of the Review, the young doctor voiced his concern for national literature and the arts. He accused his fellow Americans of a "delinquency in that, to which every other civilized nation chiefly owes its character," namely in producing a distinctive and original national literature. Painting a large canvas that placed the new republic in the family of civilizations, he warned that "the great events of our history" would be insufficient to confer "national character" on the United States if it remained without original intellect and "extraordinary men of genius." Unfortunately, it was precisely in this department that he found his country deficient. The doctor sadly concluded that the United States lacked "the pride of a nation," a literature that could do justice to its "national peculiarities," such as climate, landscape, social institutions and history, and hence would be essentially original. "Unfortunately for this country, there is no national character, unless its absence constitutes one," Channing concluded. ${ }^{25}$

Channing directed his tirade above all against the cultural subservience of his compatriots to England, the former colonizer and recent enemy, as he firmly deplored "the dependence of Americans on English literature, and their consequent negligence of the exhortation of their own intellectual powers." After identifying the "slavery to a 
common tongue" as one of the main causes of the literary dependence of the new republic, he went on to analyze the intricate relations between language and literature. How futile it was, he conceded, to "describe Niagara in language fitted for the falls at London bridge." It was only in the language of American Indians, he suggested, that one could find authentic beauty and "genuine originality." The Native Americans who refused to attend an American school, he suggested, probably realized "the debilitating effects of an English education on this national literature." ${ }^{26}$

But the apprehensive doctor also placed blame on the disadvantageous situation of the literary market and deplored the fact that American authors depended on the "literary tyranny" of the English critics and reading public, because their American readers were "too liberal and patriotick [sic] to allow the excellence of domestic manufacture." He explained this dependence on English literature, which had prevented the blossoming of American originality, from the colonial origins of the American republic, and pondered that perhaps "colonies may not be the favourites of the muses." Channing suggested related historical explanations for the surprising "barrenness of American Literature," such as the lack of a publishing infrastructure or patronage, which would allow for professional authors. But most of all he blamed his compatriots for the lack of "genuine intellectual courage" to resist the enslaving foreign influences of English literature. ${ }^{27}$

Walter Channing's contributions to the earliest issues of the North American Review have been described as the first expression of self-conscious literary criticism in the United States. ${ }^{28}$ If sometimes haltingly and convoluted, he developed a novel language of cultural nationalism that explored such essential themes as cultural influence, literary originality, criticism, taste, national language, and the relation between individual genius and national pride. Although all of these ingredients had a longer genealogy, he was blending them into an argument that was new in at least two important ways. First, he was defining national greatness in cultural terms, rather than in those of constitutional republicanism, and hence broadened the demarcation of nationhood. $\mathrm{He}$ argued that national identity not only implied victories in the traditional arenas of warfare and politics, but just as much in the fields of the arts and sciences. This is why language and literature, the topic of his articles, became so important for the creation of "national character." As another contributor to the North American Review would summarize this concern a few years later: "The rank that people take among nations is not measured by its population, wealth and military power, but often by the number of its distinguished individuals of former ages - and often by its superiority of its men of letters." ${ }^{29}$ But Channing was also keenly aware that these accomplishments not only required men of genius to express the national particularities, but just as much the participation of indigenous critics, patrons, publishers, and audiences of citizens who appreciated and shared that national culture.

16 Second, defining the greatness of the United States within the family of nations implied a new comparative perspective. In a sharp break with the Enlightenment notion of human unity, Channing started to draw cultural boundaries between his own nation and the influences from the Old World. He effectively divided the common cultural core that had united England and its colonies into separate civilizations on both sides of the Atlantic. He assumed that each nation expressed its specific identity in its own literature, language en other peculiarities. In short, national identity not only implied specific intuitions and social arrangements, but also an indigenous culture, language, 
customs, and manners that grew out of specific local geography and circumstances. This implied a nationalized concept of culture in which the unique identity of a nation, the "national peculiarities," were expressed in a range of forms, such as literature, language, morals, religion, social institutions and politics. From this unitary perspective of authenticity, "foreign" influences suddenly became pernicious. This was the main reason why the doctor warned against the contamination by European culture.

\section{Under the European Influence}

Intriguingly, the ideas about authenticity, national genius and national identity that Channing and his compatriots voiced, were influenced by notions about nationalism that were emerging in Europe. Connected to the old World Europe by ties of trade and learning, the Boston elite was well-informed about current developments in European thought and many graduates of Harvard spent one or two years in Europe to complete their studies. Two years before war broke out Dr. Channing had studied in London and Edinburgh where he had mingled with the elites of these two centers of intellectual innovation. After the war of 1812, however, many of them avoided England and rather travelled to the European continent. Influenced by the publication of an English translation of Madame De Staël's popular book about Germany, the universities of Göttingen and Berlin became a destination of choice for a new generation of pioneers of European culture, such as Edward Everett, George Ticknor, George Bancroft and Henry Wadsworth Longfellow. There they absorbed German ideas about linguistics, folklore, history and national culture that were developed by Johann Gottfried von Herder and the brothers Jacob and Wilhelm Grimm.

17 It was no coincidence that Walter Channing's publication was prompted by a review of August Wilhelm von Schlegel's works that had appeared in the London Quarterly Review earlier that year. Schlegel, who had been the travel companion of Madame De Staël, became one of the most important philosophers and disseminators of the romantic movement in Germany who forcefully stimulated an interest in the national origins of literature and the arts. In the reviewed lectures Schlegel had assessed the factors that had facilitated the development of dramatic literature in different countries from classical Greece to modern times. His comparison between the level of civilization and refinement of various nations not only discussed the role of language, criticism and taste, but most of all underlined the necessity of superior genius to achieve originality and resist the imitation of classical examples.

Although Schlegel was not yet widely known in the United States Channing was quick to adopt many of his categories and terms. ${ }^{30} \mathrm{He}$ explicitly responded to the claim, quoted at the head of his first article, that there were so many connections between nations in the modern world that "intellectual originality may justly be regarded as one of the greatest phenomena in nature." Nothing is of greater importance, the reviewer had suggested, than the manner in which "a bold and inventive imagination erects a fabric entirely of its own creation," independent from the progress of other countries. ${ }^{31}$ Dr. Channing measured the development of his own nation against the standards of authenticity that were established by this romantic theory of national character. Significantly, he referred in seventy-five instances to the concepts of "nation" and 
"country," used forty-five times a version of the words "peculiar" and "original," and repeatedly cautioned against the contagion of "foreign" influences.

Although Channing expressed much praise for Germans thinkers, he was just as likely influenced by ideas about the relation between culture and national character that had been developed in England and Scotland. His argument bears close resemblance, for instance, to the doctrine of associationism that had been developed in Britain during the eighteenth century, which held that taste depended on the association with national or individual ideas or images. This meant that aesthetics were not absolute but flourished within a specific national context. As was explained by the Scottish clergyman Archibald Alison, who had popularized this theory, a national scenery only aroused "emotions of sublimity and beauty" by mental associations that were determined by a specific historical and national context. This Scottish aesthetic theory could easily be mobilized to argue for a distinctiveness of American cultural expressions that sprung from the specific landscape and historical circumstances of the United States. Walter Channing seemed almost to quote Alison when he found that "the remotest germs of literature are the native peculiarities of the country in which it is to spring. These are diversified beyond all estimation, by the climate and the various other circumstances which produce them." ${ }^{32}$

As Channing's use of German and Scottish cultural terminology illustrates, American intellectual rivalry with the old World coincided with an implicit dependence on European norms and criteria for excellence in literature and scholarship. At the same time, Americans explored and developed essentialist conceptions of Europe as an "other" against which they defined their own emerging civilization. These two intellectual developments received urgency and new meaning in the wake of the recent war, which became the cradle of American nationalism.

\section{Winning the War of Words}

After Walter Channing had sounded the opening shots in the new battle of words in 1815 , his intellectual peers around the North American joined his quest of nationality. As if they were working on a collective program, these American intellectuals began to tackle the various questions of American cultural identity in their publications, lectures and addresses, sometimes explicitly, but more often inserted in reviews or other occasional articles. While they spoke from individual viewpoints and reached different conclusions, the transatlantic relation with the old World was the dominant basso continuo which provided a common structure for this intellectual debate. Some were merely comparing literary and cultural achievements on American soil with established European standards of taste, as had been done during the first decades after the American Revolution. But more and more they engaged in a discourse about difference that underlined the inherent originality and authenticity of American art as it was grounded in experiences, democratic principles, natural geography and indigenous peoples only to be found in the New World..$^{33}$

21 It was Walter Channing's younger brother Edward Tyrell Channing, soon to become the first Harvard professor of Rhetoric and Oratory, who perhaps best summarized the new creed of cultural isolationism and militant resistance to foreign influences, when he stated in the 1816 volume of the Review: 
that the literature of a country is just as domestick [sic] and individual, as its character of political institutions. Its charm is its nativeness. It is made for home [...] A country then must be the former and finisher of its own genius. It has, or should have, nothing to do with strangers. ${ }^{34}$

In similar vein, the question of the specific American contributions to literature, poetry and language was discussed in the North American and other periodicals in the United States, where some authors voiced a buoyant perspective on the prospects of their nation in comparison to Europe, and others shared the guarded pessimism that had marked Walter Channing's first essays.

The virtual battle over ideas soon translated into the real world as the American republic took concrete measures to curb European influence on its side of the Atlantic. When Congress passed its first tariff bill on April 27, 1816 to protect indigenous industry against European competition, it had explicitly included books with a duty of 15 percent, only exempting colleges and other scholarly institutes. After no one less than Thomas Jefferson, in his capacity as president of the University of Virginia, had petitioned for a repeal of that duty on the importation of books, the Senate in 1822 flatly refused to budge, citing arguments that seemed lifted from the debate Walter Channing had initiated. The Senatorial committee not only feared that foreign books would inundate the literary market, but also pointed at the grave danger of "these means of foreign influence" posed for American schools, where "our youth are taught by British authors, wedded to their own institutions, and exultingly proud of their country, constitution and laws." A discernment of the close association between ideas and national origins spoke from its observation that "our government is peculiar to ourselves, and our books of instruction should be adapted to the nature of the government and the genius of the people." Following the committee's conclusion that these foreign books could lead to "habits of thinking adverse to our prosperity, unfriendly to our government, and dangerous to our liberties," the US Senate upheld the tariff that intended to break the supremacy of European learning. ${ }^{35}$

One year later president James Monroe used similar arguments when he announced his famous doctrine which sought to prevent European intervention in the Western hemisphere. Since "the political system of the allied powers is essentially different" from that of the United States, he argued, his government considered "any attempt on their part to extend their system to any portion of this hemisphere as dangerous to our peace and safety." 36 The former colonial empire was not only ready to write back, but also proved prepared to act against European hegemony.

\section{The Continuation of War by Other Means}

When Ralph Waldo Emerson presented his oration on the "American Scholar" to the members of the Phi Beta Kappa Society of Harvard on August 31, 1837, he mostly repeated what so many of his American friends and colleagues had been arguing during the decades before. The difference was perhaps that he declared the mission of cultural independence accomplished. After all, he famously announced that "[o]ur day of dependence, our long apprenticeship to the learning of other lands, draws to a close. [...] We have listened too long to the courtly muses of Europe." It has become somewhat of a trope to describe his famous lecture as America's "Intellectual Declaration of Independence." That epithet was craftily coined by Oliver Wendell Holmes in the hagiographical biography that he published in 1884, and has been tirelessly repeated 
ever since. Yet, as his biographer Robert Richardson dryly remarks, comparable language of cultural resistance had been heard around Boston so often that "it had become a standard undergraduate theme topic." ${ }^{37}$

Rather than sounding the first "trumpet call" for a new war of independence, as Holmes suggested, Emerson was fighting a rearguard action in a cultural struggle that had already erupted in full force when the War of 1812 ended. In a sense, the quest for nationality that marked the first decades after 1815 was a continuation of that same war against the Old World by cultural means. As the writer James Fenimore Cooper had to remind his readers in 1837 "it is much easier to declare war, and gain victories in the field, and establish a political independence, than to emancipate the mind." Similarly, a few years later his colleague Edgar Allen Poe still felt the need to call for a "Declaration of War" in the battlefield of Letters to achieve what the Declaration of Independence had done for Government. ${ }^{38}$

The appeal of that bellicose metaphor was significant. After all, the American cultural nationalism that was propagated and negotiated after 1815 emerged from a struggle against a European culture that was now felt to be hegemonial and menacing. American writers began to deplore American "dependence," "servitude" and "idolatry" towards European cultural achievements, and theorized the dismal effects of European "influence" on indigenous genius and national pride. Just as Europeans after the Second World War began to define their own cultural achievements and national identities in opposition to an almost irresistible American imperialism of popular culture and consumerism, early Americans had done the reverse after the War of 1812. ${ }^{39}$ Both constructed a cultural opponent who threatened to seduce their compatriots with an overpowering culture that reflected foreign political and social ideals. And in both cases the cultural realignments followed fundamental shifts in international relations after a major war.

The new cultural nationalism that emerged after 1815 in the United States was not only a result of the transatlantic war. The domestic political power struggle that ended in an Era of Good Feelings, economic prosperity and territorial expansion all contributed to the upsurge of nationalism. At the same time sectionalism and the debate over slavery threatened national unity. Also, new ideas about national culture and romanticism broadened and changed the definitions of nationality which now included the arts, science and culture as areas of national pride. Yet the outcome of the war fostered a westward-orientated isolationism and turned the United States against European cultural and territorial aspirations. In that context the new transatlantic realignment and the emergence of a new national culture inevitably reinforced each other in the wake of the War of 1812. 


\section{NOTES}

1. Henry Adams, History of the United States of America During the Second Administration of James Madison (New York: C. Scribner's Sons, 1891), 220-21, 41. See also Garry Wills, Henry Adams and the Making of America (Boston: Houghton Mifflin, 2005), 382.

2. Edward Watts, Writing and Postcolonialism in the Early Republic (Charlottesville: University Press of Virginia, 1998); Lawrence Buell, "American Literary Emergence as a Postcolonial Phenomenon," American Literary History 4, no. 3 (1992).

3. Elise Marienstras, "Nationality and Citizenship," in The Blackwell Encyclopedia of the American Revolution, ed. Jack P. Greene and J. R. Pole (Cambridge, MA: Blackwell, 1994). Anthony D. Smith, National Identity (Harmondsworth: Penguin, 1991); Ernest Gellner, Nations and Nationalism, 2nd ed., New Perspectives on the Past (Malden, MA: Blackwell Pub., 2006).

4. Joyce Appleby, Inheriting the Revolution: The First Generation of Americans (Cambridge, Mass.: Belknap, 2000), 240.

5. For the post-revolutionary American interest in cultural achievements, see Kenneth Silverman, A Cultural History of the American Revolution: Painting, Music, Literature, and the Theatre in the Colonies and the United States from the Treaty of Paris to the Inauguration of George Washington, 1763-1789 (New York: Columbia University Press, 1987); Norman S. Grabo, "The Cultural Effects of the Revolution," in The Blackwell Encyclopedia of the American Revolution, ed. Jack P. Greene and J. R. Pole (Cambridge, MA: Blackwell, 1994); Michal J. Rozbicki, "The Cultural Development of the Colonies," in The Blackwell Encyclopedia of the American Revolution, ed. Jack P. Greene and J. R. Pole (Cambridge, MA: Blackwell, 1994).

6. Gordon S. Wood, Empire of Liberty: A History of the Early Republic, 1789-1815 (Oxford: Oxford University Press, 2009), 543 ff.

7. Ibid., 545.

8. David Hackett Fischer, Albion's Seed: Four British Folkways in America. America, a Cultural History (New York: Oxford University Press, 1989), 55-57, passim.

9. Benjamin Townley Spencer, The Quest for Nationality: An American Literary Campaign ([Syracuse, NY]: Syracuse University Press, 1957).

10. John Hurt Fisher, "British and American, Continuity and Divergence," in The Cambridge History of the English Language, ed. John Algeo (Cambridge: Cambridge University Press, 2004), 59.

11. Noah Webster, "Dissertations on the English Language, Etc. [1789]," in The American Literary Revolution, 1783-1837, ed. Robert Ernest Spiller (Garden City, NY: Anchor, 1967), 61.

12. David Simpson, The Politics of American English, 1776-1850 (New York: Oxford University Press, 1986); Eve Kornfeld, Creating an American Culture, 1775-1800: A Brief History with Documents (New York: Palgrave, 2001).

13. For the literary market in which Charles Brockden Brown operated, see Steven Watts, The Romance of Real Life: Charles Brockden Brown and the Origins of American Culture (Baltimore: Johns Hopkins University Press, 1994), 1-26, 131-63. See also Philip Barnard, Mark Kamrath, and Stephen Shapiro, Revising Charles Brockden Brown: Culture, Politics, and Sexuality in the Early Republic (Knoxville: University of Tennessee Press, 2004), 143; Donald A. Ringe, Charles Brockden Brown, Twayne's United States Authors Series, 98 (New York: Twayne Publishers, 1966).

14. William Dunlap, The Life of Charles Brockden Brown, 2 vols. (Philadelphia: John P. Parke, 1815), I, 3. Dunlap's biography was based on an earlier manuscript that was commissioned by Brown's family one year earlier, but had remained unfinished. The cited remarks about Brown's resistance to European standards are written by Dunlop in 1815. Watts, Romance of Real Life, 225-26. 
15. Spencer, Quest for Nationality, 80-81; [Edward Tyrrel Channing], "Brown's Life and Writings," review of The Life of Charles Brockden Brown by William Dunlap, North American Review, June 1819.

16. Samuel R. Brown, An Authentic History of the Second War for Independence: Comprising Details of the Military and Naval Operations, from the Commencement to the Close of the Recent War; Enriched with Numerous Geographical and Biographical Notes (Auburn, N.Y.: J. G. Hathaway, Kellogg \& Beardslee, 1815), 3.

17. Daniel Walker Howe, What Hath God Wrought: The Transformation of America, 1815-1848, The Oxford History of the United States (New York: Oxford University Press, 2007).

18. John C. McCloskey, "The Campaign of Periodicals after the War of 1812 for National American Literature," PMLA 50, no. 1 (1935): 264. For the paper war with England, see also Frank Luther Mott, A History of American Magazines, 1741-1850 (Cambridge, MA: Harvard University Press, 1957), $183 \mathrm{ff}$.

19. McCloskey, "Campaign of Periodicals," 267; Mott, History of American Magazines, 293-96.

20. Marshall W. Fishwick, "The Portico and Literary Nationalism after the War of 1812," The William and Mary Quarterly 8, no. 2 (1951).

21. Quoted in James Playsted Wood, Magazines in the United States (New York: Ronald Press, 1971), 43. See also Mott, History of American Magazines.

22. William Tudor, Miscellanies (Boston: Wells and Lilly, 1821), 59; Mott, History of American Magazines.

23. Robert Ernest Spiller, The American Literary Revolution, 1783-1837, Documents in American Civilization Series (Garden City, N.Y.,: Anchor Books, 1967), 109-11; William Charvat, The Origins of American Critical Thought, 1810-1835 (New York: Russell \& Russell, 1968), 174-75; Frank Luther Mott, A History of American Magazines, 1850-1865 (Cambridge, MA: Harvard University Press, 1957), check pages.

24. Amalie M. Kass, Midwifery and Medicine in Boston: Walter Channing, M.D., 1786-1876 (Boston: Northeastern University Press, 2002), 5-59; Amalie M. Kass, “'My Brother Preaches, I Practice': Walter Channing, M.D., Antebellum Obstetrician," Massachusetts Historical Review 1 (1999).

25. Although published in two subsequent issues under different titles, the two contributions should be read as one long argument, probably divided into two episodes for reasons of space. As usual, the contributions in the NAR were not signed, although most readers would be able to identify the author. [Walter Channing], "American Language and Literature," North American Review, September 1815, 261; [Walter Channing], "Reflections on the Literary Delinquency of America," North American Review, November 1815.

26. [Walter Channing], "Language and Literature."

27. Ibid., 243; [Walter Channing], "Reflections on the Literary Delinquency of America."

28. Albert D. Van Nostrand, Literary Criticism in America, The American Heritage Series, No. 16 (New York: Liberal Arts Press, 1957), ix, 3; Spiller, American Literary Revolution, 112-31.

29. [John Knapp], “National Poetry," North American Review, December 1819, 170.

30. For the American discovery of Schlegel, see Charvat, American Critical Thought, 57, 60-63.

31. [Francis Hare-Naylor], "Schlegel's Cours De Littérature Dramatique," Quarterly Review, October 1814. Although dated October 1814, the article had only appeared in London early 1815. Its author was most likely the English historian and writer Francis Hare-Naylor who had lived in Europe for many years. Jonathan Cutmore, ed., Quarterly Review Archive, http://www.rc.umd.edu/ reference/qr/index/23.html.

32. [Walter Channing], "Reflections on the Literary Delinquency of America." For the influence of Scottish aesthetic theory on William Ellery and Eward Tyrrel Channing see Charvat, American Critical Thought; Arthur W. Brown, Always Young for Liberty: A Biography of William Ellery Channing ([Syracuse, N.Y.]: Syracuse University Press, 1956), 192; Arthur W. Brown, William Ellery Channing (New York,: Twayne Publishers, 1962), 108; Robert E. Streeter, "Association Psychology and Literary Nationalism in the North American Review, 1815-1825," American Literature 17, nº 3 (1945). 
33. For an overview of some of these publications see Spiller, American Literary Revolution; Spencer, Quest for Nationality; Van Nostrand, Literary Criticism in America.

34. [Edward Tyrell Channing], "On Models in Literature," North American Review, July 1816, 207.

35. Duty on Books, 622, HR, 17th Cong., 1st sess. (January 8, 1822); Duty on Books, 627, HR, 17th Cong., 1st sess. (January 8,1822 ). The chairman of the Senatorial committee on finance that issued this report was John Holmes (1773 - 1843) of Maine. See also Catherine Seville, The International Copyright Law: Books, Buccaneers and the Black Flag in the Nineteenth Century (Cambridge: Cambridge University Press, 2007), 192.

36. President James Monroe's seventh annual message to Congress, December 2, 1823. http:// www.ourdocuments.gov.

37. Robert D. Richardson, Emerson: The Mind on Fire, a Biography (Berkeley: University of California Press, 1995), 263. See also Perry Bliss, "Emerson's Most Famous Speech," in The Praise of Folly, and Other Papers (Boston: Houghton Mifflin, 1923).

38. Spencer, Quest for Nationality, 78.

39. Richard Pells, Not Like Us: How Europeans Have Loved, Hated, and Transformed American Culture since World War Ii (New York: BasicBooks, 1997); Richard Kuisel, Seducing the French: The Dilemma of Americanization (Berkeley: University of California Press, 1993); Victoria De Grazia, Irresistible Empire: America's Advance through Twentieth-Century Europe (Cambridge, MA: Belknap, 2005).

\section{RÉSUMÉS}

This article argues that the emergence of American cultural nationalism after the War of 1812 developed in self-confident opposition to the old World, yet was thoroughly influenced by European standards of nationhood. American intellectuals who campaigned for cultural independence from Europe at the same time retained European standards of civilization and esthetics, and were thoroughly influenced by ideas about the relationship between culture and nation that developed in England and Germany. This articles discusses these postcolonial complexities are reflected in debates about American cultural identity in newly founded magazines such as the North American Review that long predated Emerson's famous "Intellectual Declaration of Independence" of 1837.

\section{INDEX}

Keywords : aesthetic theory, Anglophilia, associationism, Berlin, Connecticut Wits, Constitutional Convention, cultural identity, Edinburgh, Edinburgh Review, England, Enlightenment, Europe, Göttingen, Greece, Harvard, literary criticism, literature, London, nationalism, North American Review, Old World, Phi Beta Kappa Society, Port-Folio, Portico, Quarterly Review, romanticism, Scotland, translatio imperii, United States, University of Virginia, US Congress, War of 1812, War of Independence 
AUTEUR

JAAP VERHEUL

University of Utrecht 